\title{
Potret Perubahan Kelekatan Emosi Ibu dan Anak di Masa Belajar Online dari Rumah
}

\author{
Portraits of Changes in The Emotional Attachment of Mother and Child \\ on Learning Online from Home
}

Author:
- Eny Suprihatin ${ }^{1}$
- Ruthias Yusuarsi²
Affiliation:
1'Sekolah Tinggi Agama
Kristen Terpadu PESAT
Salatiga
skripsieny@gmail.com

25ekolah Tinggi Agama
Kristen Terpadu PESAT
Salatiga

Dates:
Submitted:
5 February 2021
Accepted:
29 September 2021
Published:
12 November 2021

\section{Copyright:}

(C) 2021. The Authors. Licensee: This work is licensed under the Creative Commons Attribution-ShareAlike 4.0 International License.

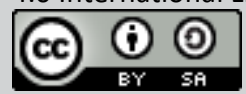

Abstract: Learning from home is a policy taken by the government to prevent the spread of COVID-19 and protect the public. This study uses a qualitative phenomenological method. To reveal the phenomena in connection with the implementation of learning from home to changes in the emotional attachment of mothers and children during the learning period from home during the COVID-19 pandemic. The respondents were six mothers and their children. The study results show that there is indeed an estrangement between mother and child in terms of emotional attachment, namely two mothers with each child. However, the mother is a strong effort as the primary attachment figure to repair the relationship and warmth so that the estrangement for two children can be attached.

[Belajar dari rumah adalah satu kebijakan yang diambil pemerintah dalam rangka menghambat penyebaran COVID-19 dan melindungi masyarakat. Penelitian ini menggunakan metode kualitatif fenomenologi. Untuk mengungkap fenomena yang terjadi sehubungan dengan pelaksanaan belajar dari rumah terhadap perubahan kelekatan emosi ibu dan anak di masa belajar dari rumah era pandemi COVID-19. Responden sebanyak enam orang ibu dan anaknya. Hasil penelitian menunjukkan dalam hal kelekatan emosi memang ada kerenggangan pada awalnya antara ibu dan anak, yaitu dua orang ibu dengan masing-masing anaknya. Namun ada usaha kuat dari ibu sebagai figur lekat utama untuk memerbaiki hubungan dan kehangatan sehingga kerenggangan untuk dua anak dapat dilekatkan kembali.]

Research Contribution: Penelitian ini mengiris dua disiplin ilmu yakni psikologi perkembangan dan pendidikan agama Kristen dalam hal kelekatan ibu dan anak.

Keywords: mother, child, emotion, christian education, online learning

\section{Pendahuluan}

wal Maret 2020 Indonesia memasuki perubahan global yang A disebabkan mewabahnya COVID-19. Global dalam pengertian 1 segala lini. Perubahan di bidang ekonomi, kesehatan, sosial, politik, serta pendidikan. Dalam bidang pendidikan, muncul fenomena belajar dari rumah sebagai salah satu kebijakan yang diambil pemerintah dalam rangka menghambat penyebaran COVID-19 dan melindungi 
masyarakat. ${ }^{1}$ Proses belajar yang umum dalam kondisi umum adalah di sekolah. Guru dan murid bertatap muka langsung dan terjadi interaksi sosial yang berlandaskan hubungan emosional. Dalam pelaksanaan belajar dari rumah menempatkan orang tua sebagai guru sekaligus pendamping bagi anak-anaknya. Dari sinilah timbul fenomena-fenomena yang menarik untuk dicermati.

Perubahan dari pembelajaran tatap muka ke pembelajaran jarak jauh di rumah siswa masing-masing menimbulkan masalah sosial yang lebih kompleks daripada teknis. Pembelajaran Jarak Jauh/PJJ yang berlangsung bagi semua jenjang mulai dari prasekolah sampai Perguruan Tinggi baik swasta mau pun negeri. Secara global, data Unesco 19 Maret 2020, ada 112 negara menetapkan kebijakan belajar dari rumah, 11 negara termasuk Indonesia, pelaksanaan belajar dari rumah dilaksanakan per wilayah tertentu bukan secara nasional.

Setiap perubahan, sekecil apapun, akan menimbulkan dampak. Apalagi seluas pandemi COVID-19 ini, berdampak multidimensi. Masalahnya, tidak setiap manusia sebagai subjek dan objek perubahan, siap menghadapi

\footnotetext{
${ }^{1}$ Dwi Ariefin, I Putu Ayub, and Darmawan, "Pemecahan Masalah Dalam Pembelajaran Melalui Kreativitas Guru Selama Masa Pandemi," PASCA: Jurnal Teologi Dan Pendidikan Agama Kristen 17, no. 1 (n.d.),

https://doi.org/10.46494/psc.v17i1.1 22.

2 Husin Husin and Sawitri Sawitri, "Covid-19: Tingkat Stres Belajar Anak-Anak Di Daerah Terpencil,” AlMadrasah: Jurnal Pendidikan Madrasah Ibtidaiyah 5, no. 2 (March 27, 2021): 101,

https://doi.org/10.35931/am.v5i2.542.

3 Anita Wardani and Yulia Ayriza, "Analisis Kendala Orang Tua Dalam Mendampingi Anak Belajar Di Rumah Pada Masa Pandemi Covid-19," Jurnal Obsesi: Jurnal Pendidikan Anak Usia Dini 5, no. 1 (2020): 772-82. https://doi.org/10.31004/obsesi.v5i1.705

4 Nika Cahyati and Rita Kusumah, "Peran Orang Tua Dalam Menerapkan Pembelajaran Di Rumah Saat

Pandemi Covid 19," Jurnal Golden Age 4, no. 01 (2020): 152-59.

https://dx.doi.org/10.29408/goldenage.v4io1.2203

5 Euis Kurniati, Dina Kusumanita Nur Alfaeni, and Fitri Andriani, "Analisis Peran Orang Tua Dalam

Mendampingi Anak Di Masa Pandemi Covid-19,” Jurnal
}

perubahan. Kualitas sumber daya manusia menentukan sikap dalam menghadapi perubahan dan hasilnya.

Sudah banyak tulisan membahas tentang perubahan yang timbul karena belajar dari rumah. Husin dan Sawitri dalam penelitiannya menulis tentang tingkat stres pada siswa-siswi Sekolah Dasar dalam menjalankan proses belajar di rumah di daerah terpencil. ${ }^{2}$ Wardani dan Ayriza menulis tentang kendala orang tua dalam mendampingi anak belajar dari rumah. ${ }^{3}$ Cahyati dan Kusumah tentang peran orang tua dalam penerapan belajar dari rumah. ${ }^{4}$ Senada dengan Cahyati adalah tulisan Kurniati,dkk yang menganalisis peran orang tua. ${ }^{5}$ Sabiq menulis tentang persepsi orang tua tentang belajar dari rumah. ${ }^{6}$ Juga ada tulisan yang mendekati dari sisi fasilitas belajar dan pembelajaran disiplin selama belajar dari rumah berkaitan dengan prestasi siswa. ${ }^{7}$ Tulisan Elsi Susanti, dkk membahas tentang kerja sama orang tua dan guru dalam pembelajaran PAUD di masa pandemi Covid19. ${ }^{8}$ Satu lagi adalah tentang upaya sekolah dan keterlibatan orang tua dalam pembelajaran dari rumah di masa pandemi, yang ditulis oleh Darmawan. ${ }^{9}$

Obsesi: Jurnal Pendidikan Anak Usia Dini 5, no. 1 (2020): 241-56.

https://doi.org/10.31004/obsesi.v5i1.541

${ }^{6}$ Ahmad Fikri Sabiq, "Persepsi Orang Tua Siswa Tentang Kegiatan Belajar Di Rumah Sebagai Dampak Penyebaran Covid 19," Civic-Culture: Jurnal Ilmu Pendidikan PKN Dan Sosial Budaya 4, no. 1 Extra (2020): 1-7. https://doi.org/10.31597/cc.v4i1.322 7 Sukarni Sukarni, "Kontribusi Pembelajaran Disiplin Belajar, Fasilitas Belajar Di Rumah, Dan Perhatian Orang Tua Terhadap Prestasi Siswa Ilmu Pengetahuan Alam," Wiyata Dharma: Jurnal Penelitian Dan Evaluasi Pendidikan 6, no. 1 (2018): 92-101. https://doi.org/10.30738/wd.v6i1.3365 8 Elsi Susanti et al., "Kerjasama Orang Tua dan Guru Dalam Pembelajaran Paud di Masa Pandemi Covid-19" 2 (2021): 1-16. https://doi.org/10.46408/vxd.v2i1.42 9 I Putu Ayub Darmawan et al., "Upaya Sekolah Dan Keterlibatan Orang Tua Dalam Pembelajaran Di Masa Pandemi Covid-19," Jurnal Komunikasi Pendidikan 5, no. 2 (July 2021): 175, https://doi.org/10.32585/jkp.v5i2.1254. 
Tulisan-tulisan di atas pada umumnya membahas fenomena Pandemi Covid-19 dan belajar dari rumah dari sisi teknis. Berupa upaya dan kerja sama orang tua dan sekolah menolong anak menyesuaikan kebiasaan baru dalam belajar. Dari sisi novelty atau kebaruan, tulisan ini akan mendekati dari sisi psikologis khususnya berhubungan dengan kelekatan emosi ibu dan anak selama masa belajar dari rumah. Kelekatan atau attachment adalah sebuah ikatan emosional yang kuat yang dikembangkan oleh anak melalui interaksi dengan orang yang memiliki arti khusus dalam kehidupannya, biasanya orang tuanya. ${ }^{10}$ Tulisan ini ingin memotret perubahan kelekatan emosi antara ibu dan anak yang terjadi di TK Pniel Terpadu khususnya kelompok B2, di Desa Celengan, Kelurahan Lopait, Kecamatan Tuntang, Kabupaten Semarang, Jawa Tengah.

\section{Metode}

Penelitian menggunakan metode Fenomenologi. Fenomenologi adalah studi tentang bagaimana mendeskripsikan sesuatu dan mengalaminya melalui indera sendiri apa yang dialami subjek. ${ }^{11}$ Husserl menyatakan fenomenologi adalah ilmu tentang penampakan (fenomena), artinya semua yang ada di balik penampakan dibuang, hanya apa yang tampak dalam pengalaman subjek yang dirumuskan esensinya dengan jernih. ${ }^{12}$ Berbeda dengan apa yang disampaikan Hegel yang lebih bersifat metafisika yaitu membicarakan apa yang ada di balik penampakan. Kant juga berpendapat serupa, kajian fenomenanya juga menyisakan konsepsi tentang noumena yang

\footnotetext{
${ }^{10}$ Handini Agusdwitanti and Siti Marliah Tambunan, "Kelekatan Dan Intimasi Pada Dewasa Awal," Jurnal Psikologi 8, no. 1 (2015).

${ }^{11}$ Dorkas Orienti Daeli and Sonny Eli Zaluchu, “Analisis Fenomenologi Deskriptif Terhadap Panggilan Iman Kristen Untuk Kerukunan Antar Umat Beragama Di Indonesia," Jurnal Sundermann 1, no. 1 (November 23, 2019): 44-50,

https://doi.org/10.36588/sundermann.v1i1.27.

12 Donny Gahral Adian, Pengantar Fenomenologi,

Kedua (Depok: Koekoesan, 2016).

13 Adian.
}

tersembunyi. Pengetahuan manusia yang terbatas hanya mampu mengkaji pada fenomena atau apa yang tampak. ${ }^{13}$

Fenomenologi mengungkap fenomen atau peristiwa pengalaman keseharian, duka, cemas, gembira, yang dimiliki setiap orang. Fokusnya adalah merenungkan peristiwa sehari-hari yang penuh makna. Peneliti fenomenologi berusaha mencari akar masalah secara mendalam tiap gejala dan peristiwa yang diteliti. Melalui tindakan, ucapan, tulisan, gambar, informasi, gerak isyarat subjek dan konteks kejadian. Arifin, mengatakan bahwa: menghilangkan atau mengabaikan hal di atas berarti kehilangan makna penting bagi seorang peneliti fenomenologi. ${ }^{14} \quad$ Meskipun peneliti fenomenologi berusaha masuk dalam batin subjek penelitiannya sehingga paham bagaimana dan apa makna yang disusun subjek di sekitar kejadian sehari-hari. Tetapi harus membuat penafsiran berdasar skema

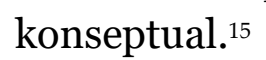

Pengumpulan data menggunakan wawancara terstruktur dan observasi sesuai indikator, kepada ibu juga anak saat belajar dari rumah dan perasaan yang dirasakan, kesulitan, tekanan, semua pengalaman batin berhubungan dengan kelekatan emosi keduanya. ${ }^{16}$ Indikator yang ditetapkan, adalah: ibu selalu mendampingi anak saat belajar di rumah, ibu selalu memberikan jawaban yang diharapkan anak, intensitas tingkat emosional ibu dan anak dibandingkan sebelum belajar dari rumah, intensitas tingkat tantrum anak, kedekatan emosional ibu dan anak, dan upaya 
mengatasi masalah emosi antara ibu dan anak. Berikutnya, penentuan lokasi penelitian dan informan. Ditentukan desa Celengan, di Kelurahan Lopait, Kecamatan Tuntang, Kabupaten Semarang, dengan mayoritas orang tua, terutama ibu, bekerja di luar rumah. Informan dalam penelitian ini dipilih dengan teknik nonprobabling sampling secara purposive sampling (sampel bertujuan). Artinya tidak setiap orang tua dan anak di TK Pniel Terpadu berpeluang terpilih sebagai informan, hanya orang tua anak TK B2 saja. Informan ditetapkan enam orang. ${ }^{17}$

Data yang diperoleh melalui wawancara terstruktur dan observasi langsung kemudian dianalisa dengan mengorganisasi data, memilih mana yang penting dan dipelajari serta dibuat kesimpulan yang dapat disajikan. Analisis lebih difokuskan selama proses di lapangan bersamaan dengan pengumpulan data. Tahap kedua menentukan fokus yaitu pada perubahan kelekatan emosional ibu dan anak. Tahap ketiga adalah melakukan seleksi (reduksi data) supaya dapat digambarkan lebih jelas dan memermudah penyajian datanya. ${ }^{18}$ Selanjutnya, proses pendekatan. Dilakukan agar mendapatkan akses dan hubungan baik. Peneliti mendapat akses masuk mudah karena mendampingi mahasiswa PPL (Oktober 2020April 2021) di TK Pniel Terpadu yang memiliki hubungan baik dengan orang tua murid. Sehingga mengurangi tingkat kecurigaan dan keengganan informan memberikan jawaban yang diharapkan.

\section{Pembahasan}

Perubahan secara umum diartikan sebagai kondisi yang berbeda dengan kondisi sebelumnya. Perubahan terjadi karena ada suatu proses yang terjadi kemudian dan menggambarkan sebelum dan setelah peristiwa terjadi. ${ }^{19}$ Berikut akan dilakukan diskusi antara teori-teori tentang perubahan kelekatan emosi dengan fakta-fakta yang terjadi di lapangan, sehubungan dengan pelaksanaan belajar dari rumah karena mewabahnya Pandemi COVID19.

\section{Kelekatan Emosi}

Temuan lapangan indikator dalam hal intensitas kelekatan emosi sebagai berikut: SM mengatakan pada awal belajar dari rumah, kelekatan dengan anak sedikit renggang karena belum terbiasa dengan kondisi. Kadang mudah kesal karena anak banyak alasan bila diajak belajar. G mengalami hal yang sama, hubungan renggang karena anak mau belajar dengan gurunya. Bila ibu memberi tekanan karena emosional maka anak tantrum. RL merasakan hal berbeda, justru secara emosi lebih dekat dengan anak, tetapi anaknya memberi reaksi berbeda sering marah karena mau belajar dengan teman-temannya. A dalam kedekatan dengan anaknya semakin dekat, hanya emosi marah naik karena kelelahan bekerja dan pada saat mendampingi belajar, anak sering membantah. L juga makin dekat dengan anak. Emosi marahnya meningkat dipicu oleh kelelahan dan anak tidak menurut saat diarahkan. SN makin dekat dengan anak. Peningkatan emosi marah terjadi pada anak karena dibatasi bermain dengan temantemannya sehingga tantrum.

Hubungan antara anak dan orang tua sebagai orang terdekat menjadi sumber emosi bagi anak. Hal ini dapat membentuk ikatan emosional yang disebut kelekatan orang tua. ${ }^{20}$

\footnotetext{
17 Lexy J. Moleong, Metodologi Penelitian Kualitatif, Cetakan Ke (Bandung: PT REMAJA ROSDAKARYA, 2014), hal.223-224.

18 Sugiyono, Metodologi Penelitian Kuantitatif, Kualitatif, dan $R \& D$.
}

19 Jelamu Ardu Marius, "Perubahan Sosial,” Jurnal Penyuluhan 2, no. 2 (2006).

https://doi.org/10.25015/penyuluhan.v2i2.2190 ${ }^{20}$ Christian Natalia and Made Diah Lestari, "Hubungan Antara Kelekatan Aman Pada Orang Tua Dengan Kematangan Emosi Remaja Akhir Di Denpasar,” Jurnal 
Mengutip pernyataan Cartney dan Dearing menyatakan: Kelekatan atau attachment adalah sebuah ikatan emosional yang kuat yang dikembangkan oleh anak melalui interaksi dengan orang yang memiliki arti khusus dalam kehidupannya, biasanya orang tuanya. ${ }^{21}$ Hubungan ini akan berlangsung dalam rentang waktu yang cukup lama diawali dengan hubungannya dengan ibu atau sosok pengganti ibu, seperti yang dikatakan dalam teori Kelekatan Bowlby. Menurut pernyataan Ainsworth, kelekatan adalah ikatan emosional yang dibentuk antar individu satu dengan lain yang bersifat spesifik dan mengikat keduanya dalam suatu kedekatan bersifat kekal sepanjang waktu. Dalam teori Etologi digunakan istilah "psychological bonding", sebuah ikatan atau hubungan psikologis antara ibu dan anak yang bertahan lama dan berkonotasi dengan kehidupan. ${ }^{22}$

Menurut teori Kelekatan Bowlby, ibu dan anak dipersiapkan secara biologis untuk saling merespons perilaku. Melalui tangisan, senyuman, dan isapan seorang bayi, muncul reaksi ibu untuk melindungi dan memenuhi kebutuhan bayinya. Dalam proses ini akan meningkat kelekatan hubungan keduanya. Sehingga berkembang hubungan saling menguntungkan atau mutuality attachment. ${ }^{23}$

Seorang anak yang memiliki orang tua yang mencintai dan memenuhi kebutuhannya akan mengembangkan model hubungan positif didasarkan pada rasa percaya (trust). Anak secara simultan mengembangkan model yang pararel dalam dirinya. Anak akan memandang dirinya berharga karena dicintai. Model ini selanjutnya akan digeneralisasi anak dari orang tua kepada orang lain. Bisa guru atau teman

Psikologi Udayana 2, no. 1 (2015): 78-88.

10.24843/JPU.2015.v02.io1.po8

${ }^{21}$ Natalia and Lestari.

22 Natalia and Lestari.

23 Inge Bretherton, "The Origins of Attachment Theory:

John Bowlby and Mary Ainsworth.," Developmental

Psychology 28, no. 5 (1992): 759-75,

https://doi.org/10.1037/0012-1649.28.5.759.

24 Bretherton. sebaya. Anak memandang guru dan teman dapat dipercaya. Sebaliknya apabila anak diasuh oleh orang yang tidak menyenangkan, akan mengembangkan kecurigaan (mistrust). Bertumbuh menjadi pencemas dan kurang mampu menjalin hubungan sosial. ${ }^{24}$

Ada dua figur lekat dalam perilaku lekat yaitu figur lekat utama dan figur lekat pengganti. Figur lekat utama adalah seseorang yang selalu siap memberi respon dan perlindungan dan perawatan fisik ketika anak menangis. Seorang yang hanya memberi perawatan fisik tetapi tidak memberi respon hangat akan menjadi figur lekat pengganti. Dalam urutan individuindividu yang dapat menjadi figur lekat utama, ibu menduduki urutan pertama. Seperti telah disebut di atas secara biologis ibu dan anak dipersiapkan untuk saling merespon tingkah laku. ${ }^{25}$

Dari hasil observasi dan wawancara $67 \%$ atau empat ibu masih menduduki posisi figur lekat utama. Saat anak menghadapi tekanan dan tegangan emosi karena perubahan cara belajar dan kebiasaan baru dalam belajar, ibu memainkan perannya sebagai figur lekat utama. Memberi respon hangat dan perlindungan. 33\% atau dua figur lekat utama ada pada nenek. Karena ibu atau ayah bekerja. Kehangatan dan afeksi yang diberikan ibu disebut kualitas ibu dan anak. ${ }^{26} \mathrm{Hal}$ ini sangat berpengaruh dalam perkembangan anak, apalagi pada kondisi darurat dan menekan. Seperti saat ini, adanya suasana dan cara belajar yang tiba-tiba berbeda. Dalam hal ini 100\% atau enam ibu memberikan kehangatan dan afeksi. Memang pada awal perubahan kebiasaan belajar dari rumah, ada 33\% atau dua orang yang sedikit renggang kedekatan emosi

\footnotetext{
25 Natalia and Lestari, "Hubungan Antara Kelekatan Aman Pada Orang Tua Dengan Kematangan Emosi Remaja Akhir Di Denpasar."

${ }^{26}$ Grace Emilia, "Afeksi Dalam Teologi Jonathan Edwards Serta Implementasinya Dalam Kehidupan Kristen," PASCA: Jurnal Teologi Dan Pendidikan Agama Kristen 16, no. 2 (November 2020): 81-93, https://doi.org/10.46494/psc.v16i2.112.
} 
antara ibu dan anak. Kemudian ibu berusaha untuk memerbaiki keadaan dengan memberikan kehangatan dan afeksi. Akhirnya kedekatan terbangun kembali, anak menaruh kepercayaan kembali kepada ibunya.

Gunarsa seperti dikutip oleh Marpaung dan Novitasari menyatakan bahwa keluarga merupakan lingkungan pertama yang pertama memberi pengaruh mendalam bagi anak. ${ }^{27}$ Dari anggota keluarga anak memeroleh segala kemampuan dasar, baik intelektual maupun sosial. Setiap sikap dan tindakan anggota keluarga menjadi teladan bagi anak dalam berperilaku. Keluarga adalah tempat pertama anak belajar dan mendapat pengetahuan tentang norma dan nilai-nilai. Oleh karena itu diperlukan suasana hangat dan harmonis dalam keluarga untuk membentuk seorang anak. Anak yang memiliki kelekatan aman pada orang tua memiliki kemandirian emosional lebih baik. ${ }^{28}$ Diperlukan intensitas yang kuat untuk dua individu, dalam hal ini orang tua dan anak, untuk memiliki kelekatan emosi. Melalui interaksi dengan orang yang memiliki arti khusus dalam kehidupan seorang anak mengembangkan ikatan emosional yang kuat.

Aspek-aspek kelekatan adalah: kepercayaan, komunikasi, dan alinasi/pengasingan. Semakin tinggi tingkat kepercayaan dan komunikasi yang intens dan hangat anak dengan orang tuanya, akan mengeratkan kelekatan emosi. Hal ini memiliki manfaat untuk memfasilitasi kecakapan dan kesejahteraan sosial anak. Anak akan memiliki harga diri lebih tinggi. Menolong anak lebih adaptif menghadapi perubahan sosial yang lebih luas di sekitarnya karena memiliki rasa aman besar dan psikologi yang sehat. Saat mengalami kecemasan dan perasaan tertekan dalam masa transisi dari kanak-kanak ke awal masa dewasa. Membantu menghasilkan hubungan positif dan dekat di

\footnotetext{
27 Junierissa Marpaung and Kiki Dian Novitasari, "Studi Deskriptif Dampak Orang Tua yang Berkonflik Bagi Anak Descriptive Study of The Impact of Conflicted Parents Toward Child," Cahaya Pendidikan 3, no. 1 (2017). https://doi.org/10.33373/chypend.v3i1.869
}

luar keluarga terutama dengan teman sebayanya.

Masa belajar dari rumah membuat waktu bersama antara orang tua dan anak menjadi lebih intens. Aspek-aspek kelekatan terutama segi kepercayaan dan komunikasi menjadi besar. $67 \%$ atau empat ibu selalu memberi jawaban yang diharapkan ketika anak bertanya, sehingga kemungkinan anak marah dan menjadi tantrum mengecil. Anak mempercayai ibunya dapat memberi jawaban untuk setiap rasa ingin tahunya.

Sebagai kesimpulan dalam hal kelekatan emosi memang ada perubahan pada awalnya antara ibu dan anak. Namun ada usaha kuat dari ibu sebagai figur lekat utama untuk memerbaiki hubungan dan kehangatan sehingga kerenggangan untuk dua anak dapat dilekatkan kembali.

\section{Belajar Dari Rumah}

Dari observasi lapangan, perubahan yang terjadi dalam hal pembelajaran di rumah adalah: bertambahnya peran ibu sebagai pendamping atau guru bagi anaknya. Ada empat ibu yang dapat mendampingi anaknya. Sementara dua orang digantikan oleh nenek (orang tua ibu) karena bekerja di luar rumah setiap hari. Dalam hal penguasaan gawai sebagai sarana mengerjakan dan mengirimkan tugas ke sekolah banyak kendala. Terutama bagi dua orang pengganti figur lekat (nenek) ibu. Masalah lain adalah kesiapan sumber daya manusia pendamping belajar di rumah, gaya belajar yang berbeda dengan anak yang didampingi, strategi dalam mengatasi masalah yang disebabkan tingkat pendidikan.

Perubahan dari pembelajaran tatap muka ke pembelajaran jarak jauh yang dalam hal ini 
disebut sebagai belajar dari rumah siswa masing-masing, menimbulkan masalah sosial yang lebih kompleks daripada masalah teknis. ${ }^{29}$ Perubahan ini menimbulkan tantangan dari sisi kesiapan sumber daya manusia baik: guru, siswa dan orang tua. Juga kurang siapnya infra struktur, seperti: kejelasan kebijakan dan aturan, kurikulum, sarana prasarana, dukungan teknologi dan internet. ${ }^{30}$ Masalah yang besar dan umum adalah masalah infrastruktur jaringan internet, terutama di tempat-tempat yang belum terpasang jaringan internet.

Secara geografis, Desa Celengan berada di lereng Gunung Rong yang cukup tinggi \pm 690 Mdpl dan kontur tanah naik turun. Kondisi ini menyebabkan jaringan sinyal buruk di daerah tersebut. Pada masa belajar dari rumah ini menjadi tantangan yang sangat signifikan dalam hubungannya dengan ketersediaan infrastruktur dalam belajar. Mengirimkan tugas-tugas, mengerjakan tugas-tugas yang dikirim dari sekolah.

Selain itu dalam model belajar dari rumah orang tua (dalam hal ini ibu) menjadi pengajar menggantikan guru. Orang tua harus membuat strategi bagaimana mengajar anak. Masalahnya tidak semua orang tua di desa memiliki kesiapan yang sama dalam belajar dari rumah. ${ }^{31}$ Ada gap yang terjadi dalam situasi ini. Terutama diakibatkan oleh masalah penguasaan teknologi orang tua dan anak.

Bagi generasi post gen $Z$ yang orang tuanya sekarang berusia antara 24-39 tahun atau generasi milenial mungkin tidak begitu signifikan. Ada dua anak atau 33\% dari responden yang didampingi oleh neneknya

\footnotetext{
29 Andina Amalia and Nurus Sa'adah, "Dampak Wabah Covid-19 Terhadap Kegiatan Belajar Mengajar Di Indonesia," Jurnal Psikologi 13, no. 2 (December 20, 2020): 214-25,

https://doi.org/10.3576o/psi.2020.v13i2.3572.

30 Aruming Tias Pudyastuti and C. Asri Budiningsih,

"Efektivitas Pembelajaran E-Learning Pada Guru PAUD

Selama Pandemic Covid-19," Jurnal Obsesi : Jurnal
}

sebagai pengganti ibu/ayah sebagai guru. Mereka kelahiran generasi X (1965-1980) yang berusia 50 tahun ke atas. Hal ini menimbulkan masalah yang signifikan. Anak menjadi tantrum karena mau belajar dengan gurunya. Tidak mau dengan neneknya karena tidak menguasai penggunaan gadget. Tentu saja menimbulkan kejengkelan di hati figur lekat pengganti dan merenggangkan kelekatan di antara mereka.

Gap lainnya adalah gaya belajar yang unik dari masing-masing anak. Bisa jadi gaya belajar ibu dulu berbeda dengan anak-anaknya sekarang. Sehingga menimbulkan ketegangan dalam hubungan emosional yang berpengaruh pada kelekatan emosi.

Tiga orang anak memiliki gaya belajar kinestetis. Anak mau belajar dengan bermain bersama teman-teman. Sedangkan kondisi tidak memungkinkan mereka bermain bersama. Ibu menjadi marah karena anak tidak mau menyelesaikan tugas yang diberikan guru. Ibu harus berstrategi mengalihkan perhatian anak untuk bermain dengan teman supaya tugas sekolah dapat dikumpulkan.

Berikutnya adalah masalah self-efficacy atau efikasi diri. Efikasi diri adalah kemampuan diri untuk memotivasi diri, menaikkan rasa percaya diri, keyakinan pada diri sendiri, dan mampu mawas diri. Seorang anak yang punya kemampuan efikasi dapat menciptakan kemandirian belajar. Menurut Bandura, seperti dikutip Tita Sari, seorang yang memiliki selfefficacy tinggi akan dapat membangun kemampuan lebih banyak dengan berusaha terus-menerus. Sebaliknya, anak dengan efikasi rendah akan terhambat kemampuan yang
Pendidikan Anak Usia Dini 5, no. 2 (January 2021): 1667-75, https://doi.org/10.31004/obsesi.v5i2.873. ${ }^{31}$ Ade Agusriani and Mohammad Fauziddin, "Strategi Orangtua Mengatasi Kejenuhan Anak Belajar Dari Rumah Selama Pandemi Covid-19,” Jurnal Obsesi: Jurnal Pendidikan Anak Usia Dini 5, no. 2 (January 6, 2021): 1729-40, https://doi.org/10.31004/obsesi.v5i2.961. 
dibutuhkannya. ${ }^{32}$ Bandura juga menyatakan bahwa segala sesuatu sangat sulit dibanding kondisi sesungguhnya. Anak dengan efikasi diri tinggi akan mengembangkan perhatian dan usahanya terhadap tuntutan situasi.

Dalam hal ini apabila efikasi diri ibu dan anak sama-sama tinggi, akan dapat mengatasi gap dalam situasi belajar dari rumah ini. Ibu dan anak akan berusaha lebih keras mengatasi kesulitan yang terjadi. Fakta di lapangan (dalam penelitian ini) lima dari enam anak masih belum memiliki efikasi diri yang cukup untuk memotivasi diri dan menciptakan kemandirian dalam belajar. Masih tergantung pada keberadaan teman juga guru yang biasa memotivasi dalam belajar saat kondisi normal.

Pada masa belajar dari rumah orang tua menjadi guru sekaligus pengawas bagi anakanaknya. Dukungan keluarga, dalam hal ini orang tua, tidak cukup hanya dalam melengkapi fasilitas belajar, tetapi yang tidak kalah penting adalah emotional support. Emotional bonding di antara orang tua dan anak justru diharapkan menguat dalam kondisi seperti ini. Juga instrumental support yang meliputi: bimbingan dari orang tua, menyediakan diri sebagai tempat anak mengadu dan berkeluh kesah karena menjadi tempat pertama yang diandalkan anak. Apalagi bagi anak usia dini, orang tua adalah satu-satunya tempat mengekspresikan cinta antara anak dan orang tua. Serta pemberian pengakuan dan apresiasi kepada anak oleh orang tuanya.

Hasil wawancara kepada orang tua, semua mengatakan emotional bonding makin menguat dalam kondisi ini. Sekalipun dua orang ibu mengatakan bukan dirinya yang menjadi guru dan pengawas bagi anaknya, melainkan neneknya, karena bekerja di luar rumah. Tetapi berusaha memberi penjelasan kepada anak, karena kondisi tidak dapat

32 Tita Tanjung Sari, "Self-Efficacy Dan Dukungan Keluarga Dalam Keberhasilan Belajar Dari Rumah Di Masa Pandemi Covid-19," Education Journal: Journal mendampingi anak belajar di rumah. Setiba di rumah berusaha memberikan perhatian dan rasa aman kepada anak.

Secara emosional rupanya belajar dari rumah meningkatkan kelelahan emosional anak maupun orang tua. Komisi Perlindungan Anak Indonesia selama masa awal pembelajaran dari rumah menerima pengaduan dari berbagai daerah sebanyak 51 kasus. Kelelahan yang disampaikan berkaitan dengan: beban tugas, tenggat waktu sempit sementara tugas banyak. Tidak cukup memiliki kuota internet untuk mengikuti pembelajaran dan materi dari guru. ${ }^{33}$

Dalam kasus ini ketersediaan jaringan internet yang baik menjadi salah satu penyebab timbulnya kelelahan emosi berkaitan dengan pengiriman tugas dan pembuatan tugas-tugas. Memang ada dua orang di desa Celengan yang menyediakan jasa pengadaan jaringan internet namun untuk daerah-daerah sulit di mana responden berada, tidak cukup kuat. Selain itu masalah kemampuan penguasaan aplikasi pada gawai juga menyumbang kelelahan emosi pada orang tua.

Hal lain adalah pengaturan waktu belajar dan bermain. Saat belajar di rumah anak-anak lebih banyak waktu bermain daripada belajarnya. Anak merasa nyaman di rumah yang menjadi daerah kekuasaannya. Masalah muncul ketika orang tua (ibu) menegakkan disiplin waktu belajar. Potensi ketidaksepakatan besar antara ibu dan anak dalam pengaturan waktu belajar. Tiga ibu mengalami kesulitan ketika menegakkan waktu belajar. Anak maunya bermain, sementara ibu mau supaya anak menyelesaikan tugas yang diberikan guru bersama anak. Timbul ketidaksepakatan dan ketegangan emosi keduanya yang menyebabkan kelelahan emosi. Supaya anak tidak tantrum sering kesepakatan dilanggar.

Educational Research and Development 4, no. 2 (2020): 127-36. https://doi.org/10.31537/ej.v4i2.346 33 Husin and Sawitri, "Covid-19: Tingkat Stres Belajar Anak-Anak Di Daerah Terpencil.” 
Perlu ada kejelasan dan aturan yang disepakati bersama. Sehingga tidak perlu harus ada hukuman dan tekanan yang dapat merusak kelekatan orang tua dan anak. Aturan diusahakan sesuai minat dan keinginan anak. Tanpa paksaan dan ancaman fisik yang dapat mencederai fisik anak.

Berkaitan dengan pendampingan ibu kepada anak selama belajar dari rumah dalam rangka membangun komunikasi sudah dilakukan oleh semua responden. Pendampingan yang diberikan dalam bentuk kehadiran ibu di samping anak. Ada usaha menghadirkan figur lekat pengganti sebelum ibu pulang kerja. Sehingga membuat anak merasa nyaman dan merasakan perlindungan. Akibatnya meningkat kedekatan ibu dan anak. Bahkan satu anak mengalami perubahan signifikan dalam hal inisiatif belajar sendiri dan minta ditunggui ibunya.

Ibu memberi semangat dengan memberikan kata-kata dorongan, memberi penjelasan, memberikan pemahaman, memeluk, dan memberikan pujian. Sesuai teori Kelekatan Bowlby, ibu dan anak mengembangkan hubungan yang saling menguntungkan. Ibu belajar meningkatkan kesabarannya dan kerendahan hati meminta maaf kepada anak ketika terpaksa berbicara tegas untuk menegakkan peraturan. Anak berkembang makin besar rasa percaya diri dan juga kemandiriannya, utamanya belajar sendiri.

Kesimpulan berkaitan dengan belajar dari rumah ada peningkatan mutu kelekatan emosi antara ibu dan anak. Ada peningkatan mutu pendampingan utamanya dalam pemberian afirmasi yang hasilnya adalah satu anak meningkat inisiatif belajar sendiri secara signifikan di semester dua ini setelah sebelumnya di semester satu sering tantrum.

\section{Kesimpulan}

Dari pemaparan hasil penelitian di atas disimpulkan, Pertama: dalam hal kelekatan emosi memang ada kerenggangan pada awalnya antara ibu dan anak, yaitu dua orang ibu dengan masing-masing anaknya. Namun ada usaha kuat dari ibu sebagai figur lekat utama untuk memerbaiki hubungan dan kehangatan sehingga kerenggangan untuk dua anak dapat dilekatkan kembali. Kedua, berkaitan dengan belajar dari rumah ada peningkatan mutu kelekatan emosi antara ibu dan anak. Ada peningkatan mutu pendampingan utamanya dalam pemberian afirmasi yang hasilnya adalah satu anak meningkat inisiatif belajar sendiri secara signifikan di semester dua ini setelah sebelumnya di semester satu sering tantrum. Begitu kompleks dampak yang ditimbulkan oleh pandemi Covid-19, penulis merekomendasikan untuk dilakukan penelitian lanjutan yang berkaitan dengan perubahan emosional ibu dan anak dari dimensi yang lain.

\section{Referensi}

Adian, Donny Gahral. Pengantar Fenomenologi. Kedua. Depok: Koekoesan, 2016.

Agusdwitanti, Handini, and Siti Marliah Tambunan. "Kelekatan Dan Intimasi Pada Dewasa Awal." Jurnal Psikologi 8, no. 1 (2015).

Agusriani, Ade, and Mohammad Fauziddin. "Strategi Orangtua Mengatasi Kejenuhan Anak Belajar Dari Rumah Selama Pandemi Covid-19." Jurnal Obsesi : Jurnal Pendidikan Anak Usia Dini 5, no. 2 (January 2021): 172940. https://doi.org/10.31004/obsesi.v5i2.961.

Amalia, Andina, and Nurus Sa'adah. "DAMPAK WABAH COVID-19 TERHADAP KEGIATAN BELAJAR MENGAJAR DI INDONESIA." Jurnal Psikologi 13, no. 2 (December 20, 2020): 214-25. https://doi.org/10.3576o/psi.2020.v13i2.357 2.

Ariefin, Dwi, I Putu Ayub, and Darmawan. "Pemecahan Masalah Dalam Pembelajaran Melalui Kreativitas Guru Selama Masa Pandemi." PASCA: Jurnal Teologi Dan Pendidikan Agama Kristen 17, no. 1 (n.d.). https://doi.org/10.46494/psc.v17i1.1 22.

Arifin, Imron. "Penelitian Kualitatif Dalam IlmuIlmu Sosial Dan Keagamaan.” Malang: Kalimasahada Press, 1996. 
Bretherton, Inge. "The Origins of Attachment Theory: John Bowlby and Mary Ainsworth." Developmental Psychology 28, no. 5 (1992): 759-75. https://doi.org/10.1037/00121649.28.5.759.

Cahyati, Nika, and Rita Kusumah. "Peran Orang Tua Dalam Menerapkan Pembelajaran Di Rumah Saat Pandemi Covid 19.” Jurnal Golden Age 4, no. 01 (2020): 152-59.

Daeli, Dorkas Orienti, and Sonny Eli Zaluchu. "Analisis Fenomenologi Deskriptif Terhadap Panggilan Iman Kristen Untuk Kerukunan Antar Umat Beragama Di Indonesia.” Jurnal Sundermann 1, no. 1 (November 23, 2019): 44-50. https://doi.org/10.36588/sundermann.vii1.2 7.

Darmawan, I Putu Ayub, Patri Alinda Nalle, Magdalena Magdalena, Marderina Marderina, and Yustina Julita. "Upaya Sekolah Dan Keterlibatan Orang Tua Dalam Pembelajaran Di Masa Pandemi Covid-19.” Jurnal Komunikasi Pendidikan 5, no. 2 (July 2021): 175. https://doi.org/10.32585/jkp.v5i2.1254.

Emilia, Grace. “Afeksi Dalam Teologi Jonathan Edwards Serta Implementasinya Dalam Kehidupan Kristen.” PASCA: Jurnal Teologi Dan Pendidikan Agama Kristen 16, no. 2 (November 2020): 81-93. https://doi.org/10.46494/psc.v16i2.112.

Husin, Husin, and Sawitri Sawitri. "Covid-19: Tingkat Stres Belajar Anak-Anak Di Daerah Terpencil." Al-Madrasah: Jurnal Pendidikan Madrasah Ibtidaiyah 5, no. 2 (March 2021): 101. https://doi.org/10.35931/am.v5i2.542.

Kurniati, Euis, Dina Kusumanita Nur Alfaeni, and Fitri Andriani. "Analisis Peran Orang Tua Dalam Mendampingi Anak Di Masa Pandemi Covid-19." Jurnal Obsesi: Jurnal Pendidikan Anak Usia Dini 5, no. 1 (2020): 241-56.

Marius, Jelamu Ardu. "Perubahan Sosial.” Jurnal Penyuluhan 2, no. 2 (2006).

Marpaung, Junierissa, and Kiki Dian Novitasari. "STUDI DESKRIPTIF DAMPAK ORANG TUA YANG BERKONFLIK BAGI ANAK DESCRIPTIVE STUDY OF THE IMPACT OF CONFLICTED PARENTS TOWARD CHILD." Cahaya Pendidikan 3, no. 1 (2017).

Moleong, Lexy J. Metodologi Penelitian Kualitatif. Cetakan Ke. Bandung: PT REMAJA
ROSDAKARYA, 2014.

Natalia, Christian, and Made Diah Lestari.

"Hubungan Antara Kelekatan Aman Pada

Orang Tua Dengan Kematangan Emosi

Remaja Akhir Di Denpasar.” Jurnal Psikologi

Udayana 2, no. 1 (2015): 78-88.

Nuryana, Arief, Pawito Pawito, and Prahastiwi

Utari. "PENGANTAR METODE PENELITIAN

KEPADA SUATU PENGERTIAN YANG

MENDALAM MENGENAI KONSEP

FENOMENOLOGI.” Ensains Journal 2, no. 1 (2019): 19-24.

Pudyastuti, Aruming Tias, and C. Asri Budiningsih. "Efektivitas Pembelajaran E-Learning Pada Guru PAUD Selama Pandemic Covid-19." Jurnal Obsesi : Jurnal Pendidikan Anak Usia Dini 5, no. 2 (January 2021): 1667-75. https://doi.org/10.31004/obsesi.v5i2.873.

Sabiq, Ahmad Fikri. "Persepsi Orang Tua Siswa Tentang Kegiatan Belajar Di Rumah Sebagai Dampak Penyebaran Covid 19." Civic-Culture: Jurnal Ilmu Pendidikan PKN Dan Sosial Budaya 4, no. 1 Extra (2020): 1-7.

Sari, Tita Tanjung. "Self-Efficacy Dan Dukungan Keluarga Dalam Keberhasilan Belajar Dari Rumah Di Masa Pandemi Covid-19.” Education Journal: Journal Educational Research and Development 4, no. 2 (2020): 127-36.

Sugiyono. Metodologi Penelitian Kuantitatif, Kualitatif, Dan R\&D. Cetakan Ke. Bandung: Penerbit ALFABETA, 2016.

Sukarni, Sukarni. "Kontribusi Pembelajaran Disiplin Belajar, Fasilitas Belajar Di Rumah, Dan Perhatian Orang Tua Terhadap Prestasi Siswa Ilmu Pengetahuan Alam." Wiyata Dharma: Jurnal Penelitian Dan Evaluasi Pendidikan 6, no. 1 (2018): 92-101.

Susanti, Elsi, Br Simamora, Sekolah Tinggi, and Teologi Simpson. "KERJASAMA ORANG TUA DAN GURU DALAM PEMBELAJARAN PAUD DI MASA PANDEMI COVID-19" 2 (2021): 1-16.

Wardani, Anita, and Yulia Ayriza. "Analisis Kendala Orang Tua Dalam Mendampingi Anak Belajar Di Rumah Pada Masa Pandemi Covid-19." Jurnal Obsesi: Jurnal Pendidikan Anak Usia Dini 5, no. 1 (2020): 772-82. 